\title{
KERAGAMAN GENETIK Aquilaria malaccensis DARI BANGKA BARAT PROVINSI KEPULAUAN BANGKA BELITUNG DAN IMPLIKASINYA UNTUK PENGELOLAAN TEGAKAN BENIH
}

\author{
Genetic diversity of Aquilaria malaccensis from Western Bangka, Bangka Belitung province \\ and its implication for manage seed stands
}

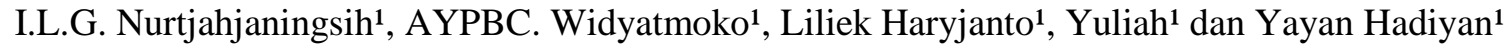

${ }^{1}$ Kontributor Utama, ${ }^{1}$ Balai Besar Penelitian dan Pengembangan Bioteknologi dan Pemuliaan Tanaman Hutan J1. Palagan Tentara Pelajar km 15, Purwobinangun, Pakem, Sleman, Yogyakarta, Indonesia email penulis korespondensi : iluh_nc@yahoo.com
\end{abstract}

Tanggal diterima: 07 Desember 2020, Tanggal direvisi: 07 Desember 2020, Disetujui terbit: 24 Desember 2020

\begin{abstract}
Aquilaria malaccensis (agarwood) is a native species to Indonesia, it produces aromatic oil. Aim in this study was to assess genetic diversity and structure of A. malaccensis from western Bangka, Bangka BelitungProvince. in order to manage seed stand to produce high quality and quantity seeds/seedlings. Leaf samples for DNA template were collected from 3 populations at western Bangka i.e. Air Gantang, Pelangas, and Simpang Gong. Amplifications of 14 RAPD markers were confirmed; 42 DNA samples of A. malaccensis were analysed using RAPD markers. Parameters of genetic diversity within population i.e., private alleles $\left(P_{A}\right)$ and unbiased expected heterozygosity $\left(u_{E}\right)$ were calculated using GeneAlex software. Genetic structure among populations were determined as genetic distance (Da), Analysis molecular of variance (AMOVA), a clustering analysis, were calculated using GeneAlex and PopTrew software. Eleven out of 14 RAPD markers produced 104 stable and polymorphic alleles; $P_{A}$ were found at Air Gantang and Pelangas with 1 and 2 alleles, respectively. The $H_{E}$ ranged between 0.133 for Simpang Gong and 0.328 for Pelangas. The Da was a moderate level (0.110. AMOVA showed significant genetic diversity among populations (14\%). A neighbor-joining tree showed that the populations were grouped into two clusters with high boostrap value, and concordance with their geographical positions. Restricted gene flow might cause a high genetic relationship among populations. Low $H_{E}$ in Simpang Gong indicated this population was prioritized to being conserved; Air gantang and Pelangas should be designed as different conservation units due to the population contained different private alleles.
\end{abstract}

Keywords: expected heterozygosity, genetic relationship, private allele, RAPD markers

\begin{abstract}
ABSTRAK
Aquilaria malaccensis (gaharu) merupakan jenis asli Indonesia, jenis ini menghasilkan minyak aromatik. Penelitian ini bertujuan untuk mengkaji keragaman dan struktur genetik A. malaccensis dalam rangka pengelolaan tegakan benih agar menghasilkan benih/bibit yang berkualitas dan berkuantitas. Sampel daun untuk sampel DNA berasal dari 3 populasi di Bangka Barat, Provinsi Kepulauan Bangka Belitung yaitu Air Gantang, Pelangas, dan Simpang Gong. Amplifikasi 14 penanda RAPD dikonfirmasi, dan 42 sampel DNA A. malaccensis dianalisis menggunakan penanda RAPD. Parameter keragaman genetik di dalam populasi parameter yaitu alel privat $\left(\mathrm{P}_{\mathrm{A}}\right)$ dan heterozigositas harapan unbiased $\left(\mathrm{uH}_{\mathrm{E}}\right)$ dihitung menggunakan perangkat lunak GeneAlex. Struktur genetik antarpopulasi menggunakan jarak genetik (Da), analisis varian molekul (AMOVA), dan analisis klaster dihitung menggunakan software GeneAlex dan PopTrew. Sebelas dari 14 penanda RAPD menghasilkan 104 alel yang stabil dan polimorfik; $\mathrm{P}_{\mathrm{A}}$ ditemukan di Air Gantang dan Pelangas, masing-masing 1 dan 2 alel. $\mathrm{H}_{\mathrm{E}}$ berkisar antara 0,133 (Simpang Gong) dan 0,328 (Pelangas). Da bernilai sedang $(0,110)$. AMOVA menunjukkan keragaman genetik yang signifikan antarpopulasi (14\%). Analisis klaster menunjukkan bahwa tiga populasi tersebut terbagi menjadi dua klaster dengan nilai bootstrap tinggi, sesuai dengan posisi geografisnya. Aliran gen yang terbatas dapat menyebabkan hubungan genetik yang tinggi antarpopulasi. Rendahnya $\mathrm{H}_{\mathrm{E}}$ di Simpang Gong menyebabkan populasi ini sangat diutamakan untuk dilestarikan; Air gantang dan Pelangas harus dirancang sebagai unit konservasi yang berbeda karena masing-masing memiliki alel privat yang berbeda.
\end{abstract}

Kata kunci : alel privat, heterozygositas harapan, kekerabatan genetik, penanda RAPD

\section{PENDAHULUAN}

Aquilaria malaccensis (Lamk) termasuk dalam famili Thymelaeaceae, genus Aquilaria. Jenis ini berbunga sepanjang tahun, namun 
mengalami puncak berbunga pada bulan Desember. Bunga dan buah A. malaccensis memiliki karakter antara lain bunga berwarna hijau kekuningan dan terletak di ujung ranting; penyerbukan dibantu oleh serangga (kupu-kupu dan semut), buah berbentuk lonjong, tumpul di ujung dan menyempit di pangkal dan berisi 1-2 biji. Apabila buah kering dan membuka, biji tersebar secara gravitasi atau dimakan oleh burung, tupai dan tikus tanah (Lian et al., 2016). Tanaman ini tersebar secara alami di Sumatera, Kalimantan dan Bangka Belitung. Infeksi oleh jamur Fussarium spp., pada tanaman ini baik secara alami dan buatan, kayu gubalnya bisa menghasilkan resin (agar) dengan wewangian yang sangat khas dan bernilai ekonomi tinggi. Resin yang dihasilkan digunakan sebagai bahan baku untuk pembuatan parfum, kosmetik, dupa dan obat (Komar et al., 2014). Harga produk gaharu dari A. malaccensis sangat tinggi, hingga Rp. 800 jt per kg (Dea, 2018). Selain untuk memenuhi kebutuhan dalam negeri, kayu gaharu juga diekspor ke negara Eropa, Saudi Arabia dan Jepang melalui Malaysia dan Singapura. Dengan semakin bertambahnya kebutuhan akan kayu gaharu, tekanan terhadap hutan alam semakin meningkat drastis, dan jumlah individu pohon garahu semakin berkurang hingga beresiko tinggi terhadap kepunahan (Komar et al., 2014).

Usaha konservasi sedang dilakukan untuk menghindarkan jenis ini dari ancaman kepunahan karena tekanan penebangan liar dan penurunan populasi di hutan alam (Komar et al., 2014; Lian et al., 2016). Selain itu, penunjukkan sumber benih A. malaccensis juga diperlukan dalam rangka penyediaan benih unggul dalam jumlah yang memadai (Widyatmoko et al., 2020). Salah satu informasi penting untuk menyusun strategi konservasi dan sumber benih adalah identifikasi populasi berdasarkan penanda DNA. Keragaman genetik suatu populasi menurun apabila terjadi penyimpangan genetik yang disebabkan oleh menurunnya ukuran populasi (Bekku et al., 2019). Penurunan ukuran populasi dapat memicu terjadinya kawin kerabat atau bahkan perkawinan sendiri (selfing) (Beseega et al., 2017). Penurunan populasi ini bisa disebabkan oleh penurunan jumlah individu maupun tidak terjadi keserempakan pembungaan atau bahkan tidak terjadi pembungaan sama sekali sehingga tidak tersedia buah/biji (Borrell et al., 2018).

Di beberapa lokasi, A. malaccensis menunjukkan pembungaan yang sangat ideal dan serempak sehingga menghasilkan biji yang berlimpah, dan anakan yang melimpah di lantai hutan terutama di bawah pohon induk (Lian et al., 2016). Namun sebaliknya, di beberapa tempat, kelimpahan bunga dan biji serta anakan tidak terjadi. Kelangkaan benih yang terjadi di beberapa lokasi akan dipenuhi dengan mendatangkan benih dari berbagai tempat lainnya, sehingga akan berpengaruh terhadap struktur genetik populasi A. malaccensis. Struktur genetik menunjukkan komposisi genetik suatu populasi yang terdiri dari frekuensi alel yang berbeda, terutama alel dominan dan alel privat. Oleh karena banyak faktor yang berpengaruh pada keragaman dan struktur genetik populasi, maka informasi genetik dari populasi A. malaccensis diperlukan dan bisa bermanfaat untuk menyusun strategi konservasi dan penetapan sumber benih.

Nilai keragaman genetik populasi bervariasi karena beberapa faktor seperti, karakter biologis, faktor alami seperti fragmentasi secara alami dan campur tangan manusia dalam pengelolaan hutan serta pembalakan liar. Populasi hutan alam A. malaccensis sudah semakin berkurang disebabkan oleh faktor-faktor di atas. Penggunaan penanda DNA, seperti random amplified polymorphism DNA (RAPD) dapat memberikan informasi yang akurat pada nilai keragaman dan struktur genetik karena bersifat netral dan nilainya tidak dipengaruhi oleh lingkungan dan ciri morfologi. Tujuan penelitian ini adalah untuk mengetahui keragaman dan struktur genetik A. malaccensis dari Kabupaten Bangka Barat. 


\section{BAHAN DAN METODE}

\section{A. Waktu dan tempat}

Penelitian keragaman genetik

A. malaccensis dilakukan mulai bulan Juni hingga Agustus 2019. Pengambilan sampel materi genetik berupa daun atau kambium dilakukan dari 3 populasi di Kabupaten Bangka Barat, Provinsi Kepulauan Bangka Belitung yaitu populasi Air Gantang, Pelangas dan Simpang Gong. Nama kecamatan, populasi, status hutan dan letak geografis disajikan pada Tabel 1. Analisis keragaman genetik dilakukan di laboratorium Genetika Molekuler, Balai Besar Penelitian dan Pengembangan Bioteknologi dan Pemuliaan Tanaman Hutan, Yogyakarta.

\section{B. Bahan dan alat penelitian}

\section{Bahan}

Bahan yang digunakan untuk pengambilan sampel di lapangan diantaranya silika gel; sedangkan bahan penelitian yang digunakan di laboratorium diantaranya bahan kimia untuk ekstrasi DNA (EDTA, Trisbase), proses PCR (Amplitaq Gold Kit) dan elektroforesis (Ethidium bromide, agarose).

\section{Alat}

Alat yang digunakan untuk mengambil sampel di lapangan diantaranya GPS, galah, gunting dan bor kayu. Alat utama yang digunakan untuk analisis keragaman genetik di laboratorium diantaranya timbangan analitik (Metller Teledo), mesin penghancur daun/kambium (Biospec Products), sentrifuge (Eppendof), berbagai macam ukuran pipet (Gilson), alat ukur konsentrasi dan kemurnian DNA (GE healthcare), mesin PCR (9700-Perkin Elmer), proses elektroforesis (Owl), dan alat visualisasi fragment DNA (Biorad).

Materi genetik dari populasi Air Gantang semuanya berupa kambium karena ketinggian pohon tidak memungkinkan untuk memperoleh daun; sedangkan materi genetik dari populasi Pelangas dan Simpang Gong sebagian besar berupa daun. Sebanyak dua sampai tiga lembar daun dengan kriteria tidak terlalu muda/tua dan bersih dari penyakit per individu pohon: dikumpulkan dan dimasukkan dalam amplop, kemudian dikemas dalam wadah (plastik klip) yang berisi silika gel untuk menyerap kadar air daun tanpa merusak struktur DNA. Sampel berupa kambium diambil menggunakan alat bor kayu, berdiameter $2 \mathrm{~cm}$ dengan panjang $5 \mathrm{~cm}$. Seperti pada sampel daun, cara penyimpanan sampel kambium juga menggunakan silika gel. Semua sampel daun dan kambium disimpan pada suhu ruang sampai proses ekstraksi DNA. Proses ekstrasi atau isolasi DNA diawali dengan menimbang sampel daun kering silika seberat $50 \mathrm{mg}$ menggunakan timbangan analitik (Mettler Teledo). Sampel dibersihkan dengan cara mengusap menggunakan alkohol $70 \%$, kemudian daun dipotong kecil-kecil dan dimasukkan dalam tube $2 \mathrm{ml}$ (safe-locked) dan dihaluskan menggunakan mesin penghalus daun (Biospec Products). Selanjutnya proses pemecahan membran sel (lisis), isolasi, pemurnian DNA mengikuti protokol sebagaimana pada penelitian sebelumnya (Nurtjahjaningsih et al., 2017). Konsentrasi dan kualitas DNA diukur menggunakan Nanovue (GE Healthcare). Untuk memperoleh hasil yang akurat, Nanovue ditera terlebih dahulu menggunakan prosedur kalibrasi yang ada di alat tersebut. Kosentrasi DNA diukur dalam satuan ng/L, sedangkan kualitas DNA diukur pada absorbansi 260/280 $\mathrm{nm}$ dengan kisaran nilai purifikasi antara 1,8 hingga 2 .

Proses PCR (poly chain reaction) merupakan proses penempelan primer DNA pada DNA uji, sekaligus perbanyakan potongan DNA target. Penelitian ini memverifikasi 14 penanda RAPD pada yang sudah melalui proses seleksi primer (screening) pada penelitian sebelumnya (Rimbawanto \& Widyatmoko, 2011). Empat belas penanda RAPD yang diverifikasi disajikan pada Tabel 2. Proses PCR, baik larutan maupun kondisi mesin PCR menggunakan protokol yang telah dilakukan oleh Nurtjahjaningsih et al. (2017). Selanjutnya 
fragment DNA hasil PCR diidentifikasi melalui proses elektroforesis. Proses elektroforesis penanda RAPD berlangsung selama kurang lebih 2,5 jam dan hasil elektroforesis divisualisasi mengunakan alat geldoc dan perangkat lunak Quantity geldoc (Biorad).

\section{Metode pengamatan}

Pengamatan terhadap kuantitas/ konsentrasi DNA dilakukan menggunakan alat nanovue (GE healthcare). Konsentrasi DNA yang dibutuhkan untuk proses PCR adalah 2,5 ng/L, sehingga apabila konsentrasi DNA melebihi persyaratan PCR, maka DNA diencerkan dengan menambah psd $\mathrm{H}_{2} \mathrm{O}$. Pengamatan terhadap kualitas DNA dilakukan menggunakan alat yang sama (Nanovue). Nilai kualitas DNA yang baik berkisar antara 1,8-2 pada absorbansi 260/280 nm. Selanjutnya pengamatan terhadap visualisasi fragment DNA dilakukan menggunakan perangkat lunak Quantity Geldoc (Biorad). Data pengamatan dikumpulkan berdasarkan ada tidaknya pita fragment pada setiap lokus penanda RAPD. Data binary (skoring) ini menunjukkan skor 1 apabila ada pita, sedangkan skor 0 menunjukkan tidak ada pita.

\section{Rancangan}

Penelitian ini menguji nilai keragaman dan struktur genetik A. malaccensis pada 3 populasi yaitu Air Gantang, Pelangas dan Simpang Gong; masing-masing jumlah sampel yang digunakan yaitu 10, 30 dan 2, sehingga total sampel sebanyak 42. Penanda RAPD yang digunakan untuk verifikasi sebanyak 14 primer. Untuk verifikasi primer menggunakan 8 sampel DNA dari 3 populasi, sehingga total sampel sebanyak $112(14 \times 8)$. Dari 14 primer tersebut dipilih primer yang bersifat stabil dalam amplifikasi dan polimorfik. Analisis keragaman populasi menggunakan 11 primer terpilih (Tabel 2) dan diujikan terhadap 42 sampel DNA, sehingga total sampel sebanyak 462 $(11 \times 42)$.

\section{E. Analisis data}

Parameter keragaman genetik di dalam populasi menggunakan alel privat dan unbiased heterozygositas harapan $\left(\mathrm{H}_{\mathrm{E}}\right)$. Alel privat merupakan alel yang hanya ditemukan pada satu populasi saja dan mencirikan kekhasan suatu populasi. Unbiased heterozygositas harapan menunjukkan keragaman gene di dalam populasi dengan mengabaikan sampel yang berkerabat, hanya memperhitungkan ukuran sampel. Nilai alel privat dan unbiased $\mathrm{H}_{\mathrm{E}}$ dihitung menggunakan perangkat lunak GenAlEx 6.5 (Peakall \& Smouse, 2012).

Tabel 1. Nama kecamatan, populasi, status hutan dan letak geografis tiga populasi A. malaccensis di Kabupaten Bangka Barat, Provinsi Kepulauan Bangka Belitung

\begin{tabular}{llll}
\hline Kecamatan & Populasi & Status hutan & Letak geografis (LS/BT) \\
\hline \hline Parittiga & Air Gantang & $\begin{array}{l}\text { Di areal kebun masyarakat dan tegakan merupakan } \\
\text { hutan alam }\end{array}$ & $01^{\circ} 35^{\prime} 40,6^{\prime \prime} / 105^{\circ} 27^{\prime} 31,2^{\prime \prime}$ \\
Simpang Teritip & Pelangas & $\begin{array}{l}\text { Di areal kebun masyarakat dan tegakan merupakan } \\
\text { hutan alam }\end{array}$ & $01^{\circ} 55^{\prime} 49,3^{\prime \prime} / 105^{\circ} 21^{\prime} 02,6^{\prime \prime}$ \\
Simpang Teritip & Simpang Gong $\begin{array}{l}\text { Di areal kebun masyarakat dan tegakan merupakan } \\
\text { hutan alam }\end{array}$ & $01^{\circ} 55^{\prime} 31,6^{\prime \prime} / 105^{\circ} 19^{\prime} 30,8^{\prime \prime}$ \\
\hline
\end{tabular}

Keterangan: LS: Lintang Selatan, BT: BujurTimur

Struktur genetik antarpopulasi ditunjukkan dengan penyusunan filogenetik dan analysis molecular variance (AMOVA). Filogenetik disusun menggunakan unweighted pair group method with arithmetic (UPGM) merupakan metode klustering dengan asumsi laju evolusi berjalan konstan. Metode UPGMA dihitung berdasarkan jarak genetik antarpopulasi (Da) dengan 1000 kali ulangan bootstrap. Filogenetik dihitung menggunakan perangkat lunak POPTREEW (Takesaki et al., 2014). AMOVA adalah metode untuk mengetahui perbedaan populasi menggunakan penanda molekuler (Excoffier et al., 1992). 
AMOVA mengelompokkan 42 individu dalam tingkat hirarki tiga populasi (Air Gantang, Pelangas dan Simpang Gong). Uji statistik menggunakan 999 permutasi. AMOVA dihitung menggunakan perangkat lunak GenAlEx 6.5 (Peakall \& Smouse, 2012).

\section{HASIL DAN PEMBAHASAN}

\section{A. Hasil}

Proses verifikasi penanda RAPD pada

A. malaccensis dilakukan terhadap 14 penanda.

Tabel 2. Nama dan jumlah penanda RAPD untuk screening, yang teramplifikasi, bersifat polimorfik dan stabil pada A. malaccensis

\begin{tabular}{llll}
\hline & Nama primer RAPD screening & Nama primer RAPD teramplifikasi & $\begin{array}{l}\text { Nama primer RAPD stabil } \\
\text { dan polimorfik }\end{array}$ \\
\hline & OPA9, OPA10, OPA11, OPA12, & OPA9, OPA10, OPA11, OPA12, & OPA9, OPA10, OPA12, \\
& OPA18, OPA19, OPD2, OPD3, & OPA18, OPA19, OPD2, OPD3, & OPA18, OPD2, OPD3, \\
& OPD5, OPG6, OPG7, OPR3, & OPD5, OPG6, OPG7, OPR3, & OPD5, OPG7, OPR3, \\
& OPR8, OPW3 & OPR8, OPW3 & OPR8, OPW3 \\
\hline $\begin{array}{l}\text { Jumlah } \\
\text { primer }\end{array}$ & 14 & 14 & 11 \\
\hline
\end{tabular}

Semua penanda yang digunakan teramplifikasi pada sekuen DNA $A$. malaccensis. Namun demikian hanya 11 penanda yang teramplifikasi secara stabil dan bersifat polimorfik, sehingga analisis keragaman genetik menggunakan 11 penanda RAPD (Tabel 2).

Karakteristik 11 penanda RAPD disajikan pada Tabel 3. Sekuen penanda RAPD berjumlah 10 pasangan basa (base pairs: bp). Jumlah alel polimorfik per penanda berkisar antara 6 hingga 13. Jumlah keseluruhan alel polimorfik sebanyak 104. Ukuran alel polimorfik antara $300 \mathrm{bp}$ hingga $1300 \mathrm{bp}$. Persentase lokus polimorfik sebesar 100\%. Karakteristik penanda tersebut menunjukkan bahwa penanda cukup baik digunakan dalam analisis keragaman genetik $A$. malaccensis.

Tabel 3. Karakteristik 11 penanda RAPD pada analisis keragaman genetik A. malaccensis

\begin{tabular}{|c|c|c|c|c|}
\hline $\begin{array}{l}\text { Nama primer } \\
\text { RAPD }\end{array}$ & Sekuen 5'-3' & $\begin{array}{l}\text { Jumlah alel } \\
\text { polimorfik }\end{array}$ & Ukuran alel (bp) & $\begin{array}{l}\text { Persentase lokus } \\
\text { polimorfik }(\%)\end{array}$ \\
\hline OPA-09 & GGGTAACGCC & 10 & $\begin{array}{l}500,600,700,800,850,900, \\
1000,1100,1200,1300\end{array}$ & 100 \\
\hline OPA-10 & GTGATCGCAG & 12 & $\begin{array}{l}500,600,650,700,750,800,900, \\
1000,1050,1100,1200\end{array}$ & 100 \\
\hline OPA-12 & TCGGCGATAG & 13 & $\begin{array}{l}300,350,400,500,550,600,700 \\
800,850,900,1000,1200,1300\end{array}$ & 100 \\
\hline OPA-18 & AGGTGACCGT & 6 & $550,700,750,850,950,1200$ & 100 \\
\hline OPD--02 & GGACCCAACC & 6 & $550,750,800,850,950,1050$ & 100 \\
\hline OPD-03 & GTCGCCGTCA & 11 & $\begin{array}{l}550,600,650,700,750,800,850 \\
900,950,1000,1100\end{array}$ & 100 \\
\hline OPD-05 & TGAGCGGACA & 12 & $\begin{array}{l}450,500,550,600,650,700,750 \\
800,900,1000,1050,1200\end{array}$ & 100 \\
\hline OPG-07 & GAACCTGCGG & 9 & $\begin{array}{l}550,600,650,700,800,900 \\
1000,1100,1200\end{array}$ & 100 \\
\hline OPR-03 & ACACAGAGGG & 11 & $\begin{array}{l}400,450,550,650,750,800,850 \\
1000,1100,1200,1300\end{array}$ & 100 \\
\hline OPR-08 & CCCGTTGCCT & 6 & $500,550,700,800,900,1000$ & 100 \\
\hline \multirow[t]{2}{*}{ OPW-03 } & GTCCGGAGTG & 8 & $\begin{array}{l}500,550,650,700,750,900, \\
1000,1300\end{array}$ & 100 \\
\hline & Jumlah alel & 104 & & \\
\hline
\end{tabular}


Parameter keragaman genetik populasi A. malaccensis disajikan pada Tabel 4. Jumlah sampel yang digunakan pada populasi Simpang Gong sangat sedikit $(\mathrm{N}=2)$ dibandingkan jumlah sampel dari dua populasi lainnya. Alel privat yang mencirikan populasi ditemukan pada populasi Air Gantang dan Pelangas, masingmasing 1 dan 2 alel. Nilai $\mathrm{uH}_{\mathrm{E}}$ berkisar antara 0,133 hingga 0,328 . Rata-rata nilai $\mathrm{uH}_{\mathrm{E}}$ sebesar 0,258 ; termasuk kategori nilai sedang.

Tabel 4. Nama populasi, jumlah sampel dan parameter nilai keragaman genetik pada populasi A. malaccensis

\begin{tabular}{lcccc}
\hline \multicolumn{1}{c}{ Nama populasi } & $\mathrm{N}$ & Alel privat & $\mathrm{uH}_{\mathrm{E}}$ & $\mathrm{SE}$ \\
\hline Air Gantang & 10 & 1 & 0,314 & 0,018 \\
Pelangas & 30 & 2 & 0,328 & 0,016 \\
Simpang Gong & 2 & 0 & 0,133 & 0,023 \\
\hline Jumlah/ rata-rata & 42 & 3 & 0,258 & 0,012 \\
\hline
\end{tabular}

Keterangan: $\mathrm{N}$; jumlah sampel daun/kambium yang digunakan, $\mathrm{uH}_{\mathrm{E}}$; keragaman genetik harapan unbiased, $\mathrm{SE}$; standar error

Nilai rata-rata jarak genetik antar tiga populasi termasuk sedang $(\mathrm{Da}=0,110)$. Analisis dendrogram menunjukkan bahwa tiga populasi membentuk 2 klaster; populasi Air Gantang dan Pelangas membentuk klaster yang berbeda dengan tingkat kepercayaan $100 \%$, sedangkan populasi Simpang Gong berdekatan dengan populasi Pelangas. Hal ini menunjukkan bahwa kedekatan genetik sesuai dengan kedekatan secara geografis.

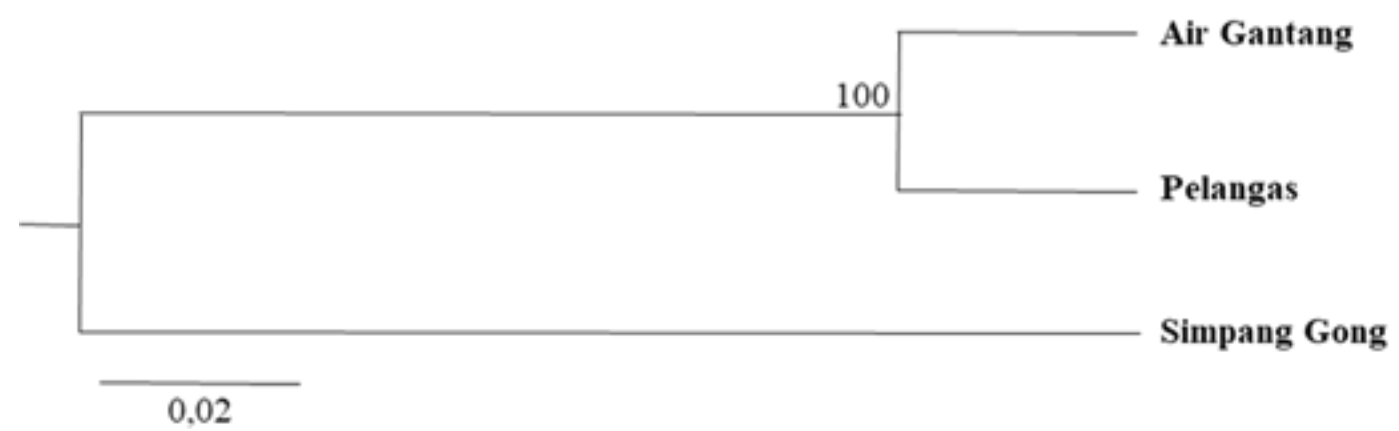

Gambar 1. Dendrogram antar tiga populasi A. malaccensis di Kabupaten Bangka Barat, Propinsi Bangka Belitung

Hasil analisis AMOVA menjelaskan hasil individu memiliki nilai tinggi dan signifikan, analisis dendrogram dan menunjukkan bahwa masing masing sebesar $14 \%$ terjadi antar perbedaan genetik antarpopulasi dan antar populasi dan $86 \%$ terjadi antar individu.

Tabel 3. Analisis AMOVA mengelompokkan 42 individu A. malaccensis dalam populasi dan individu

\begin{tabular}{lccccc}
\hline \multicolumn{1}{c}{ Sumber keragaman } & Db & JK & KT & varians (\%) & $p$-value \\
\hline Antar populasi & 2 & 88.181 & 44.090 & 14 & $0.001 * * *$ \\
Antar individu & & & & 86 & $0.001 * * *$ \\
\hline
\end{tabular}

Keterangan: db: derajat bebas, JK: jumlah kuadrat, KT: kuadrat tengah

\section{B. Pembahasan}

Salah satu kelemahan penanda RAPD adalah ketidakstabilan amplifikasi sehingga sering memberikan hasil yang berbeda-beda. 
Ketidakstabilan ini dapat diminimalkan dengan cara mengulang proses PCR pada primer dengan protokol PCR dan sampel yang sama (Nurtahjaningsih et al., 2018). Verifikasi amplifikasi 14 penanda RAPD pada penelitian ini membuktikan ketidakstabilan penanda RAPD. Dari 14 penanda RAPD yang telah dipilih melalui proses seleksi primer (screening primer) pada A. malaccensis (Rimbawanto dan Widyatmoko 2011), hanya 11 penanda yang dapat digunakan. Oleh karena amplifikasi penanda RAPD bersifat tidak stabil, maka untuk memberikan hasil yang lebih akurat sebelum melakukan analisis keragaman genetik, tindakan verifikasi amplifikasi perlu dilakukan.

Jumlah sampel DNA yang digunakan sering menjadi perdebatan dalam analisis keragaman genetik. Sampel sebanyak 20-30 merupakan jumlah ideal untuk dilakukannya analisis keragaman genetik. Namun demikian, jumlah ideal tersebut tidak selamanya dapat terpenuhi karena keterbatasan ketersediaan sampel di lapangan (hutan), terutama pada jenisjenis tanaman terancam punah. Penggunaan parameter keragaman genetik, $\mathrm{uH}_{\mathrm{E}}$ (unbiased expected heterozygosity), dan standar error dapat menjadi solusi ketika jumlah sampel yang digunakan jumlahnya terbatas (Pruett \& Winker, 2008). Parameter $\mathrm{uH}_{E}$ merupakan salah satu parameter keragaman genetik yang mempertimbangkan jumlah sampel yang terbatas baik jumlah maupun ketidakseimbangan sampel (Peakall \& Smouse, 2012). Oleh karena itu, penggunaan parameter $\mathrm{uH}_{\mathrm{E}}$ pada tiga populasi tersebut, cukup mempresentasikan kondisi di lapangan. Tiga populasi A. malaccensis yang digunakan pada penelitian ini merupakan populasi alam yang dikelola oleh masyarakat setempat. Keragaman genetik populasi Air Gantang dan Pelangas tergolong sedang. Hal ini menunjukkan bahwa dua populasi ini tergolong baik untuk dapat dikelola sebagai sumber benih A. malaccensis. Keragaman genetik di populasi tersebut dapat dipertahankan bahkan ditingkatkan apabila memperhatikan sistem pembungaan dan pola perkawinan. Sistem pembungaan yang serempak dan berlimpah merupakan kondisi ideal hutan untuk menghasilkan pola perkawinan acak (Nurtjahjaningsih et al., 2007). Pola perkawinan acak akan menghasilkan benih dengan keragaman genetik tinggi karena tidak ada perkawinan memilih. Pada perkawinan acak, serbuk sari menyerbuki banyak pohon betina sehingga benih yang dihasilkan merupakan hasil perkawinan dari berbagai pohon jantan (Sork, 2016). Perkawinan acak juga menghindari penyerbukan antar kerabat, sehingga menghasilkan benih dengan laju kawin silang (outcrossing) yang tinggi (Nurtjahjaningsih et al., 2012). Sebaliknya, pada musim pembungaan yang parsial dan jumlahnya sedikit, terjadi sistem perkawinan yang memilih (Robledo-Arnuncio et al., 2004). Serbuk sari dari pohon jantan yang sama akan menyerbuki banyak pohon betina. Konsekuensi dari musim pembungaan yang seperti ini akan menghasilkan benih hasil penyerbukan sendiri atau berkerabat secara genetik karena serbuk sari berasal dari satu pohon jantan (Nurtjahjaningsih et al., 2007). Benih hasil selfing atau berkerabat secara genetik ditandai dengan benih tanpa embrio (Beseega et al., 2017), bibit albino (RobledoArnuncio et al., 2004), bibit dengan tingkat adaptasi terhadap lingkungan dan penyakit yang rendah (Kang et al., 2003).

Jarak genetik antar tiga populasi tersebut termasuk besar (rata-rata $\mathrm{Da}=0,110$ ). Analisis dendrogram dan AMOVA menunjukkan bahwa populasi Air Gantang dan Pelangas merupakan populasi yang berbeda; $100 \%$ terpisah dan $14 \%$ perbedaan genetik antarpopulasi. Selain itu, apabila dilihat data alel frekuensi, pada dua populasi tersebut ditemukan alel privat. Secara geografis, Air Gantang dan Pelangas berjarak cukup jauh (60 $\mathrm{Km})$. Hal ini menunjukkan pembatas geografis yang cukup kuat untuk terjadinya aliran gen (gene flow) melalui serbuk sari, mengingat media penyerbukan pada A. malaccensis dibantu oleh serangga (Lian et al., 2016). Selain itu, dari pengamatan di lapangan, semai jenis ini 
banyak ditemukan di bawah pohon induk. Meskipun belum banyak diteliti, namun diperkirakan biji A. malaccensis lebih dominan disebarkan secara gravitasi. Biji memiliki selaput tipis seperti sayap, namun biji juga bisa dimakan oleh burung, tupai dan tikus tanah sehingga sebarannya kemungkinan tidak terlalu jauh (Lian et al., 2016). Selain itu, masyarakat sekitar hutan juga menerapkan pembatasan pencampuran bibit dari daerah lain (Haryjanto, komunikasi pribadi).

\section{Implikasi untuk pengelolaan tegakan benih $A$. malaccensis}

Pada jenis tanaman terancam punah, usaha konservasi ditujukan untuk menjaga jumlah maupun keragaman genetik agar tidak semakin punah (Lee, 2000). Penelitian ini menunjukkan bahwa keragaman genetik A. malaccensis dari populasi Bangka Barat tergolong sedang. Berdasarkan nilai $\mathrm{uH}_{\mathrm{E}}$, populasi Simpang Gong memiliki keragaman genetik paling rendah, sehingga untuk menjaga kelestarian sumber daya genetik, konservasi genetik populasi tersebut harus diprioritaskan. Informasi sistem perkawinan pada A. malaccensis belum diketahui, sehingga untuk meningkatkan keragaman genetik, keterlibatan beberapa populasi terutama populasi dengan nilai keragaman genetik tinggi (Pelangas dan Air Gantang) harus diprioritaskan dalam strategi pembangunan hutan tanaman untuk tujuan komersial. Sebaliknya, dalam strategi konservasi, karena populasi Pelangas dan Air Gantang memiliki alel spesifik (alel privat) maka pembangunan tegakan benih dari dua populasi ini harus dipisah untuk menghindari percampuran kekhasan alel privat yang dimiliki masing-masing populasi.

Besarnya nilai jarak genetik antarpopulasi menunjukkan keterbatasan aliran gen antarpopulasi. Serangga sebagai penyerbuk pada A. malaccensis dengan kapasitas menyebarkan serbuk sari pada jarak pendek (dalam kisaran meter), dibandingkan sebaran serbuk sari pada jenis tanaman yang dibantu angin (dalam kisaran kilometer), cukup efektif menjaga perbedaan genetik antarpopulasi, seperti pada Calophyllum inophyllum (Nurtjahjaningsih et al., 2012). Efektifitas serangga dalam menyebarkan serbuk sari akan maksimal, apabila pembungaan pada A. malaccensis serempak. Oleh karena itu, suatu hutan tanaman/tegakan benih harus mencapai pembungaan yang serempak, sehingga terjadi perkawinan acak antarpohon induk. Besarnya jarak genetik antarpopulasi juga menunjukkan keterbatasan aliran gen melalui biji/benih. Dalam mengelola tegakan benih yang ada, masyarakat menerapkan pembatasan pencampuran benih dari daerah lain, sehingga masyarakat menjaga keaslian genetik di daerahnya masing-masing.

Analisis dendrogram dan AMOVA menunjukkan bahwa tiga populasi membentuk 2 klaster dan perbedaan genetik yang tinggi antarpopulasi. Seperti disebutkan sebelumnya bahwa pembangunan sumber benih harus melibatkan populasi Pelangas karena populasi ini memiliki nilai keragaman genetik tertinggi, sehingga populasi Pelangas bisa diprioritas pada seleksi awal. Selain itu, analisis dendrogram tersebut juga bisa digunakan sebagai sistematika pengambilan sampel untuk pembangunan sumber benih berdasarkan 2 klaster tersebut.

\section{KESIMPULAN}

Keragaman genetik tiga populasi A. malaccensis di Kabupaten Bangka Barat, Provinsi Kepulauan Bangka Belitung termasuk sedang. Populasi Pelangas memiliki keragaman genetik tertinggi sedangkan Simpang Gong memiliki nilai terendah. Analisis hubungan kekerabatan antarpopulasi menunjukkan perbedaan genetik yang tinggi antarpopulasi Air Gantang dan Pelangas. Jarak geografis merupakan pembatas yang cukup efektif terjadinya gene flow antarpopulasi pada A. malaccensis. Untuk membangun plot infusi genetik, 3 populasi tersebut dapat dilibatkan bersama-sama dalam satu plot dengan tujuan 
menambah keragaman genetik. Sebaliknya, untuk membangun plot konservasi, populasi Air Gantang dan Pelangan harus dipisahkan untuk menjaga ciri khas genetik masing-masing populasi. Selain itu, untuk meningkatkan keragaman genetik, keserempakan pembungaan di dalam populasi harus diupayakan.

\section{UCAPAN TERIMA KASIH}

Seluruh penulis memberikan kontribusi yang sama pada tulisan ini. Penelitian ini didanai oleh Dinas Kehutanan Pemerintah Daerah Bangka Belitung. Penulis mengucapkan terima kasih kepada Kepala Dinas Kehutanan Propinsi Bangka Belitung beserta staf yang telah memberikan banyak dukungan sehingga terlaksananya penelitian ini. Ucapan terima kasih juga diucapkan kepada Sdri. Wahyunisari yang telah banyak membantu dalam pekerjaan di laboratorium.

\section{DAFTAR PUSTAKA}

Bekku, Y. S., Kurokochi, H., Matsuku, Y., Nishi, N., \& Lian, C. (2019). Genetic structure of Pinus parviflora on Mt. Fuji in relation to the hoarding behavior of the Japanese nutcracker. Ecophere, 10(4), 1-13.

Beseega, C., Pometti, C., Campos, C., Saidman, B., \& Vilardi, J. (2017). Implications of mating system and pollen dispersal indicates for management and conservation of the semiarid species Prosopis flexuosa (Leguminosae). Forest Ecology and Management, $\quad 400, \quad 218-227$. https://doi.org/10.1016/j.foreco.2017.06.007

Borrell, J. S., Wang, N., Nichols, R. A., Buggs, R. J. A., \& Buggs, R. J. A. (2018). Genetic diversity maintained among fragmented populations of a tree undergoing range contraction. Heredity, 121, 304-318.

Dea. (2018). Cerita pengusaha kayu gaharu: Sekilo gaharu bisa seharga Rp 800 juta,. Tribunbanjarmasin.Com.

Excoffier, L., Smouse, P. E., \& Quattro, J. M. (1992). Analysis of molecular variance inferred from matric distnaces among DNA haplotypes: application to human mitochondrial DNA restriction data. Genetics, 131, 479-491.

Kang, K. S., Bila, A. D., Harju, A. M., \& Lindgren, D. (2003). Estimation of fertility variation in forest tree populations. Forestry, 76, 329343.

Komar, T. E., Wardani, M., Hardjanti, F. I., \& Ramdhania, N. (2014). In situ and Ex situ conservation of Aquilaria and Gyrinops: $A$ review (Bismark, E. Santoso, \& A. P. Tampubolon (eds.)). Center for Conservation and Rehabilitation Research and Development International Tropical Timber Organization (ITTO) - CITES Phase II Project.

Lee. (2000). Genetic diversity of a tropical tree species, Shorea leprosula Miq. (Dipeterocarpaceae), in Malaysia: implications for conservation of genetic resources and tree improvement. Biotropica, 32(2), 213-224.

Lian, L. C. S., Leong, L. ., Hoo, L. K., Ting, L. C., Hong, N.., \& Siong, K. N. K. (2016). Conservation action plant for the threated agarwood species Aquilaria malaccensis (Thymelaeaceae) in peninsular Malaysia.

Nurtahjaningsih, I. L. G., Herawan, T., Rachma, R. P., \& Rimbawanto, A. (2018). Pengujian penanda Random Amplified Polymorphism DNA untuk mengetahui kestabilan genetik klon jati (Tectona grandis). Jurnal Pemuliaan Tanaman Hutan, 12(2), 105-135.

Nurtjahjaningsih, I. L. G., Saito, Y., Tsuda, Y., \& Ide, Y. (2007). Genetic diversity of parental and offspring populations in a Pinus merkusii seedling seed orchard detected by microsatellite markres. Bulletin-Tokyo University Forest, 118, 1-14.

Nurtjahjaningsih, I. L. G., Sukartiningsih, Saranti, A., Sulistyawati, P., \& Rimbawanto, A. (2017). Kekerabatan genetik anakan alam ulin (Eusideroxylon zwageri TEIJSM. \& BINN.) menggunakan penanda Random Amplified Polymorphism DNA. Jurnal Pemuliaan Tanaman Hutan, 11(1), 25-31.

Nurtjahjaningsih, I. L. G., Sulistyawati, P., Widyatmoko, A., \& Rimbawanto, A. (2012). Karakteristik pembungaan dan sistem perkawinan nyamplung (Calophyllum inophyllum) pada hutan tanaman di Watusipat, Gunung Kidul. Jurnal Pemuliaan Tanaman Hutan, 6(2), 65-80. Penelitian.

Peakall, R., \& Smouse, P. E. (2012). GenAlEx 6.5: genetic analysis in Excel. Population genetic software for teaching and research an update. Bioinformatics, 28(19), 2537-2539.

Pruett, C. L., \& Winker, K. (2008). The effect of sample size on population genetic diversity estimates in song sparrows Melospiza melodia. 


\section{J. Avian Biol, 39, 252-256.}

Rimbawanto, A., \& Widyatmoko, A. Y. P. B. C (2011). Identifikasi Aquilaria malaccensis dan A. microcarpa menggunakan Penanda RAPD. Jurmal Pemuliaan Tanaman Hutan, 5(1), 2330.

Robledo-Arnuncio, J. J., Alia, R., \& Gil, L. (2004). Increased selfing and correlated paternity in a small population of a predominantly outcrossing conifer, Pinus sylvestris. Molecular Ecology, 13, 2567-2577.

Sork, V. L. (2016). Gene flow and natural selection shape spatial patterns of genes in tree populations: implication for evolutionary processes and applications. Evolutionary Application, 9, 291-310.

Takesaki, N., Nei, M., \& Tamura, K. (2014). POPTREEW: Web version of POPTREE for Constructing Population Trees from Allele Frequency Data and Computing Some Other Quantities. Molecular Biology Evolution, 31(6), 1622-1624.

Widyatmoko, A., Harijanto, L., Yuliah, \& Nurtjahjaningsih, I. L. G. (2020). Laporan Hasil Penelitian. 